\title{
USTANOVENIE NITRIANSKEHO BISKUPSTVA V ROKU 880 A OTÁZKA KATEDRÁLNEHO CHRÁMU
}

\author{
The Establishment of the Bishopric of Nitra in 880 and the Question \\ of the Nitra Cathedral
}

\author{
Andrej Botek
}

DOI: 10.17846/CL.2021.14.1.3-22

\begin{abstract}
BOTEK, Andrej. The Establishment of the Bishopric of Nitra in 880 and the Question of the Nitra Cathedral. In 880 Pope John VIII consecrated the Frankish Benedictine Wiching as a bishop of the "holy Church of Nitra" and placed him under the jurisdiction of St. Method, "the most dignified archbishop of the holy Moravian Church". This step was a result of a long development in the ecclesiastical, jurisdictional and power spheres not only on the territory of Great Moravia, but especially in the Central European region where the East Frankish, Great Moravian and Pannonian regions intersected and in which, over the years, many contradictory trends appeared. This article deals with the formation of the Bishopric of Nitra in 880 against the background of the general Christianisation in the Great Moravian area. The formation of the Bishopric is generally regarded by scholars as the formal emergence of the Pannonian/Great Moravian archdiocese. The study also presents the history of the Bishopric of Nitra after the departure of Bishop Wiching (890/893), during the restoration of the Great Moravian archdiocese in 899 and during the decline of Great Moravia after 907. It also studies sacral architecture of Nitra in the 9th century, focusing on its sacral topography.
\end{abstract}

Keywords: Bishopric of Nitra, Great Moravia, Christianisation, sacral architecture

\begin{abstract}
„Založenie“ nitrianskeho biskupstva roku 880 musíme vnímat na pozadí zložitých dobových udalostí, ale aj dovtedajšieho vývoja v mocenskej i cirkevnej sfére na území Vel'kej Moravy, Panónie i Bavorska (ako súčasti Východofranskej ríše). Jednostranný vplyv bavorského kléru na Velkej Morave (Morave i Nitriansku) bol výsledkom po vítazných avarských vojnách na konci 8. storočia a s nimi súvisiacej synody „na Dunaji“ zvolanej synom Karla Velkého Pipinom r. 796 (italský král v rokoch $781-810$ ). Diskutovala sa tu kristianizačná politika územia porazených Avarovi, na ktorom žilo i slovanské obyvatel'stvo (Kožiak 2006, 132; Illáš 2017, 183). Okrem bavorských diecéz, bezprostredne susediacich s dobytým územím (Salzburg a Pasov) sa stretnutia zúčastnil i aquilejský patriarcha Paulinus, ktorý vyhotovil aj záznam. Väčšinou sa odborníci domnievajú, že už na tomto zhromaždení sa vyčlenili hranice pôsobenia Aquileje a bavorských diecéz (Špetko 1988, 26), ktorým Karol Velký (768 - 814, cisár od 800) zveril dobyté územia avarského kaganátu, i ked'v dochovaných záznamoch sú len podrobné ustanovenia s ohladom na platnost' krstu podla spôsobu, ako bol vysluhovaný ${ }^{2}$ Výnos Ludovíta Nemca (od 826 bavorský král, východofranský
\end{abstract}

1 Oslabenú avarskú moc postupne atakovali slovanské kmene, naposledy sa listinne udávajú poslovia Avarov na franskom dvore v roku 822 (Pohl 2002, 323).

2 Na konci záznamu synody sa píše: „Potom sa biskupi venovali iným bližšie neurčeným otázkam“ (Ratkoš 
král 843 - 876) z roku 829, kde potvrdzuje pôsobenie salzburského arcibiskupstva na západ a juh od Ráby a Rabice a pasovského biskupstva východne a severne od tejto línie (MMFH III 2011, 93-96), zodpovedá zrejme staršej dohode. Aquilea mala svoje aktivity končit na rieke Dráve, čo potvrdil už roku 811 Karol Velký (Kožiak 2006, 133)³. Dominantnú kristianizačnú úlohu zohrávali u nás franskí kňazi, pričom sa zdá, že istú dobu súperili o pôsobnost̉ na Velkej Morave Salzburg a Pasov (Curta 2019, 116, Goldberg 2006, 137), až kým sa definitívne nepresadil vplyv pasovského biskupstva ${ }^{4}$.

Tento status bol narušený príchodom byzantskej misie solúnskych bratov Konštantína-Cyrila $(827$ - 869) a Metoda $(815 ?-885)$ r. 863 na pozvanie kniežata Rastislava (846 - 870). Rastislav istotne neuvažoval výlučne nad vieroučným poslaním tejto misie, ale videl v nej možnost̉ vybudovat vlastnú cirkevnú organizáciu, nezávislú od franského centra, a tým posilnit svoje osamostatňovacie úsilie (Ivanič 2011, 127) ${ }^{5}$. Od uvedeného okamihu sa zrejme začína napätie medzi cyrilo-metodskou misiou a ňou zavádzanou slovanskou liturgiou a bavorským klérom latinského obradu ${ }^{6}$. Po odchode solúnskych bratov s vyučenými žiakmi (či už pôvodne mali namierené do Konštantínopola, Aquileje, alebo Ríma) ${ }^{7}$ to bol opät výlučne franský klérus, resp. ním vychovaní domáci kňazi latinského obradu. Situácia sa však skomplikovala - činnost̉ byzantskej misie sledoval i panónsky knieža Kocel' (861 - 874/876) a rovnako tu vycítil možnost' osamostatnenia sa (aspoň cirkevne) od salzburského arcibiskupstva, ktoré na jeho území vykonávalo jurisdikciu (Gallusová - Herucová 2013, 113). Kocel’ Metoda, vracajúceho sa z Ríma, poslal spät s posolstvom dvadsiatich velmožov a žiadal jeho vysvätenie za biskupa. Podla Života Metoda to bol on, kto navrhol obnovit dávne panónske biskupstvo, odvodzujúce pôvod od apoštolského učeníka sv. Andronika (Život Metoda, VIII; Život Metoda, 2013, 51). Pápež Hadrián II. (869 - 872) túto starobylú metropolu so sídlom v Sirmiu/Srieme (dnes Sriemska Mitrovica v Srbsku), ktorá zanikla počas avarských vpádov r. 582, obnovil niekedy v druhej polovici roku 869; sv. Metoda vysvätil za biskupa a ustanovil panónskym arcibiskupom (Hnilica 1988, 87). Povaha Metodovho biskupstva a diecéznych pomerov nie je dodnes úplne vyjasnená8.

1964, 153). Uvedenú vetu, hoci sa na ňu starší autori odvolávajú, však neobsahuje neskoršie publikované znenie v MMFH IV (porovnaj MMFH IV, 2013, 7). Predpokladá sa, že v tejto poznámke je zahrnuté i rokovanie o územných deleniach medzi diecézami. Nepriamo sa poukazuje na text O obrátení Bavorov a Korutáncov z roku 870 kde sa udáva územie v Panónii, ktoré mal Pipin prisúdit správe salzburského arcibiskupstva (Kožiak 2006, 139). Viacerí autori tvrdia, že toto delenie nezohladňovalo staršiu jurisdikciu Ríma nad Panóniou.

3 Z toho je zrejmé, že v Panónii už koncom 8. stor. pôsobili rôznorodí misionári, čo implikuje ich možný prienik aj severne od Dunaja. Až do príchodu misie sv. solúnskych bratov pôsobili na území Slovenska a Moravy franskí kňazi z pasovského biskupstva, menej aj salzburského arcibiskupstva. Úplne neboli zrejme potlačené ani prieniky aquilejských klerikov, čo možno dosvedčuje "adriatický" charakter niektorých vel'komoravských sakrálnych stavieb (Illáš 2011, Botek, 2014, 59), či pôsobenie kňaza Jána z Benátok v diplomatických službách Svätopluka I (Bača 2016, 153; Charvát 2014, 226).

4 O priebehu sporov medzi Salzburgom a Pasovom podrobne Dopsch 1986.

5 Je pravdepodobné, že výprava Ludovíta Nemca proti Rastislavovi a jeho obliehanie Devína roku 864 súviselo s príchodom byzantskej misie a vyhnaním franského duchovenstva (Vavák 2015, 114).

6 Naproti tomu R. Marsina (2013, 104-105) predpokladá, že k tomu nemohlo dôjst', lebo Konštantín a Metod nemohli ihned' začat celoplošne so slúžením slovienskej liturgie, pretože k nej museli najprv vychovat adeptov, čo bol zdíhavý proces. Preto pasovskí kňazi podla neho nevideli najprv v ich činnosti bezprostrednú hrozbu.

7 Rôzne názory súhrnne zhrnul Hnilica 1988, 127-128.

8 Pápež najprv „bulou“ Gloria in excelsis Deo kniežatám Rastislavovi, Svätoplukovi a Kocelovi oznamuje poslanie Metoda (zrejme ako legáta) pre všetky uvedené kniežatá - teda pre územia Moravy, Nitrianska i Panónie (Život Metoda, VIII; Život Metoda, 2013, 50), až následne došlo na Kocelovu žiadost’ k Metodovej 
Metodovou biskupskou konsekráciou roku 869 a jeho určením na „stolec sv. Andronika“ vznikol vo velkomoravskom a panónskom priestore, ktorý franské duchovenstvo pokladalo za výlučnú záujmovú sféru, vážny cirkevno-jurisdikčný konkurent, čo predznamenalo rázne protiopatrenia bavorského episkopátu. Odzrkadluje to v textovej forme spis O obrátení Bavorov a Korutáncov (De Conversione Bagoariorum et Carantanorum), ktorý skoncipovali bavorskí biskupi v roku 870. Okrem vymenovávaní vlastných kristianizačných zásluh a nárokov na panónske územie, útočia na Metoda, ako na votrelca, ktorý na území salzburského arcibiskupstva učí protiprávne a zavádza nežiaduce novoty (Conversio 12; Conversio, 2011, 279 a 283). Neostalo však pri tom, ale Metoda zajali, súdili a skoro tri roky zadržiavali internovaného v bavorských kláštoroch, často v tvrdých podmienkach. Podstata sporu je zaznamenaná v Živote Metoda v obžalobe „V našej oblasti učís“. Na čo sa Metod háji odpoved’ou, kde spomína územnú jurisdikciu Ríma: „[...] lenže ona je svätého Petra“ (Život Metoda, IX; Život Metoda, 2013, 51)9. Prepustený bol až 873 po rozhodnom zákroku pápeŽa Jána VIII (872 - 882), ktorý napísal listy bavorským biskupom, královi Ludovítovi a vojvodovi Karolmanovi ${ }^{10}(865-880)$ a poslal svojho legáta Pavla z Ankony, aby Metoda osobne sprevádzal, nie však ku Kocel'ovi, ale ku Svätoplukovi ${ }^{11}$ ( 871 - 894, do 870 nitrianske knieža). Pápež vo svojich listoch prízvukoval Metodovu panónsku ordináciu i dávnu rímsku jurisdikciu nad ňou.

Metod sa roku 873 vrátil na Vel'kú Moravu, odkial' medzičasom (istotne nie hned' po Svätoplukovom vítazstve roku 871) vyhnali franské duchovenstvo (Život Metoda, X; Život Metoda, 2013, 52). To sa však vrátilo po Forchheimskom mieri r. 874 (Marsina 2013, 106), a tak sa opät obnovili napätia medzi Metodom a jeho slovienskou školou a franským klérom, ktoré strpčovali celý jeho d’alší život i dielo. Metod musel svoju pôsobnost’ obmedzit’ len na Svätoplukovu ríšu - Panóniu po Kocelovej smrti (874 - 876?) bezprostredne ovládli Frankovia. Zdá sa však, že až do roku 880 bolo Metodovo biskupské postavenie síce formálne (titulárne) viazané na panónsku provinciu, ale inak pomerne volné (Betti 2014,215) a len postupne sa utvárali podmienky na jeho novú územnú viazanost'. Pravdepodobne po Forchheimskom mieri prišiel na Velkú Moravu aj benediktín Wiching (nitriansky biskup 880 - 891/893?) ${ }^{12}$, ktorý sa stal jedným zo Svätoplukových

biskupskej konsekrácii, ktorá de facto stavia na obnovení panónskej provincie. Metod sa z Ríma odobral práve ku Kocelovi, na čo Blatnohrad opustil archypresbyter Riphald - salzburským arcibiskupom určený správca Kocel’ovej dŕžavy (Steinhübel 2014, 223). Otázku, či sv. Metod bol ustanovený za sídelného biskupa v Sirmiu, alebo všeobecne misijného biskupa, využijúc starý zvyk udelovat novým biskupom formálne zaniknuté diecézy, dodnes historici diskutujú. Je možné, že panónska ordinácia sv. Metoda bola len titulárna a Sirmium nebolo zamýšlané ako jeho faktické sídlo, ale ako opora v tradícii staršej, ako boli nároky bavorského episkopátu. Tým by Metodovo postavenie ako biskupa bolo pomerne volné, viazané viac na misijné aktivity v slovanských krajinách (Hnilica 1988, 89; Marsina 2013, 106). Existuje aj názor, že Metodove biskupstvo bolo v prvej etape viazané na osobu vládcu (Kocela), ktorý mu mal zabezpečit pokojn épôsobenie (Gallusová - Herucová 2013, 118 a inde). Na druhej strane Panóniu, ako zamýšlané tažiskové územie, by podporoval list Jána VIII. z roku 873, ktorým vyzýval srbské knieža Mutimíra, aby sa navrátil do panónskej diecézy, kde bol menovaný biskup (MMFH III, 2011, 138-139; Bagin 1982, 71).

9 Je príznačné, že bavorskí biskupi sa venujú len jurisdikcii nad Panóniou a nie nad Velkou Moravou. Zrejme to vychádza zo skutočnosti, že roku 870 Východofranská ríša Vel'kú Moravu po odstránení Rastislava a neskoršej internácii Svätopluka mocensky ovládala a nehrozilo nebezpečenstvo, že by v tejto situácii Metod mohol pôsobit na jej území.

10 Zachovali sa dôrazné listy pápeža Jána VIII. salzburskému arcibiskupovi Adalwinovi, pasovskému biskupovi Hermanrichovi, frizinskému biskupovi Annonovi a bavorskému vojvodovi Karolmanovi. Miernejšie píše aj královi Ludovítovi Nemcovi (MMFH III, 2011, 125-128 a 133-136; publikoval už Ratkoš 1964, 178-181).

11 Čo mohlo byt’ aj výsledkom straty dôvery v Kocela, ako možného Metodovho protektora (Gallusová Herucová 2013, 119-120).

12 V starších prácach sa spomínal ako „švábsky“ benediktín (napr. Marsina 1985, 74). V dobových textoch sa 
poradcov (Bagin 1982, 103). Metodovu prácu nehatil len odpor franského kléru, ale postupne strácal oporu aj vo Svätoplukovi, ktorý viac nadŕžal cudzím poradcom. Franské duchovenstvo obviňovalo Metoda $\mathrm{z}$ heretického učenia a slávenia liturgie v slovienskom jazyku, a tak pápež Ján VIII. listom zo 14. júna 879 povoláva Metoda do Ríma (MMFH III, 2011, 156-157) ${ }^{13}$. Je možné, že celý spor predložil na riešenie pápežskej kúrii Svätopluk pomocou svojho vyslanca Jána z Benátok ${ }^{14}$ - mohlo by to vyplývat z listu, ktorý pápež adresoval v rovnaký deň Svätoplukovi (MMFH III, 2011, 153-156).

Metodov pobyt v Ríme je tažiskový pre celé cyrilometodské dielo i pre dejiny vel'komoravskej cirkevnej provincie a nitrianskeho biskupstva. V podstate sa zopakoval úspech z rokov 868 869 - pápež Ján VIII. v liste z júna 880 (známom ako Indstriaetuae) uznal Metoda za pravoverného a povolil bohoslužby v slovienskom jazyku s dodatkom, že Evanjelium sa má najprv čítat' latinsky a pre Svätopluka, ak chce, sa omše majú slúžit v latinčine (MMFH III, 161-173). Súčasne označuje Metoda ako arcibiskupa „cirkvi moravskej“ a oznamuje Svätoplukovi, že kňaza Wichinga, „[...] ktorého si k nám poslal, vysvätili sme ako zvoleného biskupa svätej cirkvi nitrianskej; prikázali sme mu, aby svojho arcibiskupa vo všetkom poslúchal [...]“ (MMFH III, 2011, 169-170). D́alej povzbudzuje Svätopluka, aby poslal podla uváženia i iného kňaza, či diakona, vhodného na biskupské svätenie, aby arcibiskup (Metod) a dvaja biskupi (Wiching + nový) mohli sami svätit potrebných biskupov (MMFH III, 2011, 170). V uvedenom liste máme teda jednoznačne potvrdené nitrianske sídelné biskupstvo ako súčast’ Metodovej „moravskej“ arcidiecézy. Od spomenutej udalosti uplynulo minulý rok 1140 rokov. Nitrianske biskupstvo sa tak stáva historicky prvou známou diecézou na našom území, ktorá, asi so storočnou prestávkou, pokračuje do súčasnosti.

Vyvstáva otázka územného rozsahu nitrianskeho biskupstva, ktorá nie je nikde pramenne podchytená. Viacerí autori predpokladajú, že územie diecézy sa mohlo kryt’ s územím nitrianskeho kniežatstva a zasahovat’ až do Gemera, Novohradu, Spiša a Zadunajska (Judák 2011, 19). Nitrianske biskupstvo vzniká na území, na ktoré si podla starších dohôd robil nárok Pasov. Kedže proti uvedenému pasovský biskup Engelmar (874 - 897) v Ríme neprotestoval, zrejme túto skutočnost' akceptoval (Baláž 2015, 14 a inde) ${ }^{15}$.

Na tomto mieste je vhodné zamysliet’ sa nad niektorými skutočnostami. V prvom rade je to otázka volby Nitry ako diecézneho biskupského sídla. Nitra s okolím má už v 6. - 8. storočí jednu z najväčších koncentrácií sídliskovej štruktúry, čo potvrdzuje jej špecifické postavenie ako hospodársko-správneho centra (Hanuliak 2019, 76, Ruttkay 2012, 120, Bednár - Ruttkay 2014, 230) a kryštalizačné jadro územia, z ktorého (ako sa dnes všeobecne usudzuje) sa vytvorilo niekedy začiatkom 8. storočia Nitrianske kniežatstvo. Nitra je rozhodne jedným z najvýznamnejších politických a kristianizačných centier včasnostredovekej strednej Európy (Bednár 2012, 145). Bezprostrednú nitriansku sídelnú aglomeráciu, husto osídlenú už od praveku, tvorilo v 9. storočí niekolko hradísk a viacero osád so špecializovanou výrobou (Pieta-Ruttkay 2018, 24-25, Hanuliak, $2019,86)^{16}$. V staršej literatúre sa predpokladalo, že kniežacie sídlo bolo na vyvýšenine nedaleko dnešného piaristického kostola (napr. Šášky 1981, 13), archeologické výskumy posledných rokov preukázali, že najvýznamnejšie miesto s najprepracovanejšou obrannou konštrukciou sa

však uvádza ako Ostrogót, či Alaman (Havlík 1992, 221). Zrejme bol odchovancom kláštora v Reichenou (Bagin 1982, 72).

13 Je príznačné, že pápež oslovuje Metoda ako „arcibiskupa panónskej cirkvi“, čo korešponduje s našimi skôr uvádzanými úvahami o formálnej titulárnej jurisdikcii.

14 V rokoch 874 - 880 patril ku hlavným poradcom a diplomatom na Svätoplukovom dvore (Bača 2016, 153; Charvát 2014, 226).

15 Wiching mu možno zaručil vplyv v centrálnej časti Vel'kej Moravy (Baláž 2015, 18).

16 Staršie názory uvažovali o počte 6 rôzne opevnených hradísk, podrobnejšie archeologické výskumy dnes tento počet redukujú na 4 (Šalkovský 2019, 223). 
nachádzalo na hradnom kopci s rozlohou 13 ha (Bednár 2012, 148; Ruttkay 2012, 136; Hanuliak 2019 , 76). Aj v porovnaní s inými dobovými sídliskovými útvarmi v bezprostrednom dunajskom regióne je jasné, že Nitra zohrávala klúčovú úlohu už pred svojím začlenením do Velkej Moravy, k čomu došlo okolo roku $833{ }^{17}$ po anexii moravského kniežata Mojmíra I. (pred 833 - 846). Prvý známy nitriansky knieža Pribina (? - 833, panónske knieža 840 - 861) bol aj s rodinou a družinou vyhnaný a po strastiplnej púti mu nakoniec král Ludovít Nemec dal do spravovania čast' Panónie, kdesi na južnom cípe Blatenského jazera (dnes Balaton, Madarsko), kde vybudoval svoje hlavné sídlo - Blatenský hrad (Mosaburg, dnes Zalavár) ${ }^{18}$.

Práve s osobou Pribinu je spojená zmienka o najstaršom písomne doloženom kostole nielen na našom území, ale v oblasti stredovýchodnej Európy vôbec. Podla vsuvky v spise O obrátení Bavorov a Korutáncov ,jemu vysvätil niekdajší arcibiskup Adalram (821 - 836) kostol za Dunajom na jeho vlastnom majetku zvanom Nitrava" (Conversio 2011, 11; Conversio 2011, 273, Špetko 1988, 28). V každom prípade existencia krestanského chrámu svedčí o významnom postavení Nitry vo vtedajšej geopolitickej situácii. Postavenie samostatného centra si Nitra uchovala aj v neskoršom vel'komoravskom období, ked’ sa stala akoby údelným kniežatstvom „následníka trónu“ - za panovania Rastislava v nej sídlil Svätopluk a za vlády Mojmíra II. (894 - 907?) jeho brat Svätopluk II (894? - 899). Aj z týchto reálií je zrejmé, že aj po Mojmírovej anexii bola Nitra významným velkomoravským správnym a cirkevným centrom, možno hovorit aj o akejsi sídelnej dualite s oficiálnym vládnym sídlom (zrejme na Morave na mikulčických Valoch). Určité samostatné postavenie nitrianskeho kniežatstva je zrejmé aj z dobových dokumentov, napr. ako „Regnum Zventibaldi“ $\mathrm{z}$ Fuldských análov, alebo z protestného listu bavorských biskupov z roku 900 a ešte z Kozmovej kroniky (König 2017, 10). Rovnako si významné postavenie zachovalo i v dobe prvých Arpádovcov. Kedže v období konsekrácie nitrianskeho kostola dominoval na našom území franský klérus, stala sa Nitra popri civilnom správnom centre zrejme aj sídlom cirkevnej správy. Dá sa predpokladat', že pasovský biskup tu zriadil achypresbyteriát (Judák 2011, 18), podobne, ako to bolo v Pribinovej Panónii. Išlo teda o hierarchický predstupeň, z čoho logicky vyplýva aj jeho vol'ba na biskupské sídlo. Viacerí autori tu predpokladajú aj kláštor a školu na výchovu domáceho kléru. Zdá sa, že Nitra bola silným oporným bodom franských misií a tento charakter nestratila ani po príchode byzantskej misie. Prvý historicky známy nitriansky biskup Wiching tu mal určite pevné zázemie a aj z toho dôvodu mohla na ňu padnút volba. V každom prípade môžeme očakávat', že po svojej konsekrácii urobil všetko pre to, aby v Nitre pôsobenie franského kléru posilnil, prípadne eliminoval slovienskych duchovných. Vyplýva to logicky z jeho konfrontačného vztahu s arcibiskupom Metodom a jeho celkovým postojom k slovienskej liturgii.

Vynárajú sa tu aj úvahy, či na našom území nemohli existovat aj diecézy v staršom, predcyrilo-metodskom období, ktoré sa mohli stat základom neskoršieho cirkevno-správneho členenia, pričom by takou mohla byt práve Nitra. V tejto súvislosti nitriansky biskup Jozef Vurum (1827 1838) predpokladal v Nitre biskupstvo v 4. storočí za markomanskej královnej Frigitil, ktorá podla

17 Rok 833 je pravdepodobný, kedže gróf Ratbod, u ktorého hladal Pribina útočisko, sa stal v tom roku správcom Východnej marky (Tönsmeyer 2013, 29; Illáš 2017, 191). Žial', slovenský preklad Tönsmeyerovej štúdie je v niektorých častiach nepresný, aj protivýznamový.

18 Pribina sa najskôr odobral k správcovi Východnej marky Ratbodovi, ktorý bol možno jeho príbuzný. Po krste v Traismaueri došlo k rozporom a Pribina is družinou odišiel hladat útočisko najprv u Bulharov, následne u slavónskeho kniežata Ratimíra. Nakoniec gróf Salacho sprostredkoval zmier s Ratbotom a Pribina sa usádza v Panónii. Na svojom panstve, ktoré neskôr dostal od krála Ludovíta do vlastníctva, vybudovali so svojím synom Kocelom 31 písomne zaznamenaných kostolov (Conversio 2011, 11-13; Conversio 2011, 273-277 a 280-282). 
neho v Nitre sídlila ${ }^{19}$ a získala pre ňu biskupa Suniasa (Bugan 2007, 91). Tento názor sa všeobecne odmieta a Frigitiline královstvo sa hladá skôr na území Dolného Rakúska (Kolník 2012, 37). Mohla však vzniknút cirkevná organizácia formou archypresbyteriátov, sídliacich okrem Nitry aj v iných dôležitých vel'komoravských centrách (Bratislava, Trenčín, a pod.). Existenciu staršieho biskupstva v Nitre by mohli podporovat' i zmienky vo Vatikánskom tajnom archíve, kde sú ako nitrianski biskupi pred Wichingom uvedení už spomenutý Sunias a Alkuin (Bugan 2007, 91)20. Alkuina uvádza ako nitrianskeho biskupa tzv. Pilgrimovo falzum (MMFH III, 2011, 219) ${ }^{21}$. Podla tohto falza mal Alkuin spravovat ako biskup Nitru údajne za čias pápeža Eugena II. (824 - 827) (Judák 2011, 18). Vzhladom na nejasné historické údaje nemôžeme jednoznačne tvrdit, že v Nitre už pred rokom 880 existovalo biskupstvo. Iná je však otázka, či na našom území nemohli pôsobit „misijní biskupi, prípadne biskupi viazaní na mníšsku komunitu. Bez konkrétnych písomných prameňov to však ostáva len v polohe nepravdepodobnej hypotézy.

Dôležitým dôsledkom, ktorý vyplýva z rozboru pápežských dokumentov z roku 880 je skutočnost', že z pôvodne vol'nejšie koncipovaného Metodovho biskupského poslania, titulárne viazaného na Panóniu, sa stáva arcidiecézna štruktúra. Metod je už nazývaný arcibiskupom „cirkvi moravskej“, z formulácie o Wichingovi ako o jemu podriadenom sufragánovi možno jednoznačne uzatvárat arcidiecézne členenie so sídelnými biskupstvami. Nevieme presne, kde bolo Metodovo sídlo, podla všetkého sa volalo Morava a odborníci sa prikláňajú k jeho stotožňovaniu s cirkevným okrskom v lokalite Sady v Uherskom Hradišti (Galuška 2014, 83)22. Arcidiecéza však ostala organizačne nedobudovaná. Ján VIII. síce povzbudzoval Svätopluka, aby vyslal aj dalšieho vhodného kandidáta na biskupské svätenie, čím by sa docielil počet troch biskupov, umožňujúci svätit podla potreby aj d’alších, nemáme však žiadne správy, že by k uvedenému došlo. Naopak, všetky dalšie udalosti potvrdzujú názor, že sa tak nestalo. Na Velkej Morave namiesto funkčnej arcidiecézy vznikol napätý dualizmus medzi arcibiskupom Metodom a nitrianskym biskupom Wichingom. Metodovu pozíciu stažoval aj fakt, že Svätopluk sa viac prikláňal k Wichingovi, čo možno spôsoboval aj jeho mocenský vzrast (a kalkulácie výhodnejšej západnej orientácie), takže Metoda pre svoje zámery viac nepotreboval (Bowlus 1995, 216, Betti 2014, 151). Môžeme temer s istotu tvrdit', že Wiching z Nitry vytvoril profranskú a protimetodovskú základňu ${ }^{23}$. Presný priebeh sporov medzi Wichingom a Metodom nepoznáme, ale všeobecne sa o ňom píše na viacerých miestach Života Metodovho (napr. Život Metoda, XII, XIII; Život Metoda, 2013, 53-54) a výrazne v Theofylaktovom Živote Klimenta ${ }^{24}$. Je možné, že konflikt viedol až k Wichingovej exkomunikácii, ako by sa dalo vyvodzovat' z listu pápeža Štefana V. (885 - 891) Svätoplukovi z apríla 885: „Kliatba však, ktorú on (Metod) vyriekol [...] uvalí sa na jeho hlavu“ (MMFH III, 2011, 189; Ratkoš 1964, 199).

19 Markomanská královná Frigitil sa koncom 4. stor. obrátila na milánskeho arcibiskupa sv. Ambróza so žiadostou poučenia o krestanskej viere a poslanie biskupa. Správu zaznamenal Ambrózov životopisec Paulus (Bagin 1981, 27; Judák 2011, 18).

20 Uvedení biskupi sú zaznačení na základe neskorších materiálov a preto tento údaj nemôže byt relevantný (Judák 2011, 472, pozn. 5).

${ }^{21}$ Pasovský biskup Pilgrim $(971$ - 991) sa usiloval získat povýšenie svojej diecézy na arcibiskupstvo a pomocou falošných listín sa snažil dokázat', že Pasovu, ako nástupcovi zaniknutej loršskej diecézy podliehali aj biskupstvá v Panónii a na Velkej Morave (podrobnejšie: Fichtenau 1964).

22 P. Selucký $(2010,110)$ zastáva názor, že Metodovým sídlom bolo hradisko sv. Klimenta pri Osvětimanoch na Morave.

${ }^{23}$ Zo Života Metoda XII sa dá usudzovat, že franskí duchovní (možno sám Wiching) sfalšovali pápežský list v neprospech Metoda a tak ho šírili (Škoviera 2012, 53).

24 To je však mladšie dielo z prelomu 11. a 12. storočia, ktoré síce využíva starosloviensku predlohu, ale je poznačené aktuálnym rozkolom východnej a západnej cirkvi (Škoviera 2013, 97). 
Možno toto bol dôvod, prečo sa Wiching, alebo jeho zástupcovia, stažovali na Metoda u pápežskej kúrie, pričom ho zrejme opätovne obviňovali z heréz a porušovania prísahy. Okrem listu pápeža Štefana V. Svätoplukovi o tom svedčí aj inštrukcia legátom - biskupovi Dominikovi a kňazom Jánovi a Štefanovi, ktorých pápež poslal na Vel'kú Moravu vyriešit situáciu. Štefan V. zakazuje sloviensku liturgiu, Gorazdovi, ktorého Metod určil za svojho nástupcu, zakazuje vykonávat úrad, predvoláva ho do Ríma ${ }^{25}$ a uvaluje tvrdé sankcie proti „vzdorovitým a neposlušným“. Pápež sám však nie celkom dôveroval správam, lebo v liste formuloval odsúdenie voči Metodovi (ešte nevedel, že už nežije) „ak sa tak preukáže“ (MMFH III, 2011, 189, Ratkoš 1964, 199). Po smrti sv. Metoda 6. apríla 885 sa nitriansky biskup Wiching stal jediným hierarchom na Vel'kej Morave. Využijúc pápežove sankcie zlikvidoval Metodovo dielo a cyrilo-metodských učeníkov, ako nám to podrobne opisuje Život Klimenta, nechal vyhnat z Velkej Moravy (Škoviera 2010, 89-92; Život Klimenta VII-XIII; Život Klimenta, 2013, 116-118) ${ }^{26}$. Jediným cirkevným hierarchom, a teda de facto do vymenovania nového arcibiskupa aj najvyšším správcom celej arcidiecézy, sa stal Wiching. V podstate nastala pre neho situácia vhodná na to, aby bol menovaný za „vel'komoravského“ arcibiskupa. O takýchto jeho aktivitách však nemáme žiadne správy. Zdá sa, že Wiching nemal v úmysle zachovat a budovat' vel'komoravskú provinciu, ale ju považoval za jurisdikčné územie bavorských biskupstiev. Môžeme tak súdit’ i zo skutočnosti, že ked’ začiatkom 90-tych rokov ${ }^{27}$ Vel'kú Moravu opustil a stal sa poradcom cisára Arnulfa (východofranský král' 887 - 899, od 896 cisár), usiloval sa roku 899 získat post pasovského biskupa (Judák 2011, 19; Baláž 2015, 19). Po jeho odchode nastala v cirkevnej oblasti na Vel'kej Morave faktická kríza ${ }^{28}$. Franskí kňazi, pôsobiaci na území Vel'kej Moravy, sa pravdepodobne cítili viazaní na svoje diecézy a správali sa ako na svojom, prípadne misijnom území. Nebolo možné priamo svätit nových kňazov, udelovat sviatost' birmovania, rozhodovat'v cirkevných záležitostiach, atd'. Tieto úkony sa dali realizovat alebo mimo domácej pôdy, alebo cielenou návštevou zahraničného biskupa. Velkomoravská diecéza sa dostala do silnej závislosti od bavorských centier, pravdepodobne hlavne pasovského biskupstva. Nemáme žiadne správy o cirkevno-správnej situácii. Rím nevymenoval nového arcibiskupa, ani biskupov a nemáme vedomosti o tom, že by niektorá bavorská diecéza tu zriadila archypresbyteriát. Nitra však zrejme nad’alej fungovala ako miestne cirkevné centrum, predpokladáme tu sústredenie kléru i existenciu kláštora, ktorý mohol zabezpečovat cirkevnú správu aj na okolí29.

Roku 899 vyslal pápež Ján IX. (898 - 900) na Vel'kú Moravu arcibiskupa Jána a biskupov Daniela a Benedikta, ktorí tu vysvätili jedného arcibiskupa a troch biskupov (Bagin 1981, 112; Judák

25 Gorazd je spomínaný nepriamo v inštrukcii v hl. XIV: „Nástupcovi, ktorého sa Metod opovážil určit po sebe napriek ustanoveniam všetkých svätých otcov, z našej apoštolskej moci zakážte vykonávat úrad, kým nepríde k nám osobne [...]“ (MMFH III, 2011, 193; Ratkoš 1964, 201).

26 Podla životopiscových údajov išlo o 200 „služobníkov oltára“ - teda o kňazov, tých, čo mali nižšie svätenia, a zrejme aj reholníkov. Celkový počet vrátane žiakov bol iste vyšší. Viacerí autori však predpokladajú, že klerici domáceho velmožského pôvodu nemohli byt vyhnaní, ale sa utiahli do rodových sídel a hradísk a boli vylúčení z možnosti verejného pôsobenia. Predpokladá sa, že takto mohol dopadnút aj Gorazd (Hnilica 1988, 146; Škoviera 2010, 104).

27 Jeho odchod z Vel'kej Moravy sa neudáva jednotne. Uvažuje sa s rokmi 890-891 (Judák, 2011, 19 a 62), kedže 891 mal pôsobit na Velkej Morave ako Arnulfov posol, alebo rok 893 (napr. Below - Meinecke 1907, 67).

$28 \mathrm{~V}$ podstate to bola mocenská nevýhoda aj pre Svätopluka, lebo Wichingove znalosti pomerov zrejme využili franskí lídri (Gluchman 2018, 22).

29 Mnohí autori predpokladajú benediktínsky kláštor na vrchu Zobor. V povesti o Svätoplukovi pražský kanonik Kozmas spomína na Zobore pustovníkov (Kozmova kronika česká; Kozmova kronika česká, 1964, $365)$. 
$2011,19)^{30}$. Paradoxne máme informácie o obnovení „velkomoravskej provincie“ i počte biskupstiev z uvedeného protestného listu bavorských biskupov, ktorí sa voči tejto udalosti ohradzovali (list publikoval Ratkoš 1964, 206-211, najnovšie MMFH III, 2011, 196-208) ${ }^{31}$. Vel'komoravská cirkevná provincia tak bola obnovená z pápežského rozhodnutia, čím dostala primerané uzna$n^{32}{ }^{32}$. Odborníci predpokladajú, že arcibiskupským stolcom bolo staršie Metodovo sídlo - zrejme cirkevný komplex Sady pri Uherskom Hradišti (Galuška 2014, 83) - a d’alšie biskupstvá situujú do Nitry (Bagin 1981, 113; Judák 2011, 19). Ostatné z biskupských sídel sú predmetom rozsiahlej diskusie ${ }^{33}$, ktorú na tomto mieste nebudeme spomínat. Stažnost' bavorského episkopátu je založená na tvrdení, že Vel'ká Morava patrí oddávna do pasovskej diecézy a vysvätením uvedených hierarchov došlo $\mathrm{k}$ narušeniu jej celistvosti ${ }^{34}$. Samozrejme, ani v tej dobe nebolo možné, aby v jednom biskupstve pôsobilo viacero nezávislých biskupov (Zubko 2016, 21), avšak bavorskí biskupi zamlčali viaceré dôležité skutočnosti - vôbec nespomínajú arcibiskupa Metoda ani Vel'komoravskú arcidiecézu a Nitru (hoci bola jednoznačne na území, ktoré Pasov považoval $\mathrm{v}$ zmysle dohôd z prelomu 8. a 9. storočia za svoju sféru) tendenčne vylučujú ${ }^{35}$, aby nemuseli uznat, že už Wichingovým svätením bolo nitrianske biskupstvo z diecézy Pasova vyčlenené, a to priamo pápežským rozhodnutím (Baláž 2015, 21 a inde). Túto skutočnost̉ bavorskí biskupi len nedávno sami použili v spore s cisárom Arnulfom proti Wichingovi, ktorý sa s jeho podporou roku 899 chcel stat pasovským biskupom. Vtedy argumentovali, že je to nemožné, lebo dotyčný je právoplatným biskupom v Nitre (Baláž 2015, 19). Hoci v iných textoch sme v súlade so všeobecným presvedčením sami uvažovali nad Nitrou ako z jedným zo štyroch obnovených biskupstiev (napr. Botek 2014, 30) a je to logické i v zmysle nadväzovania na diecéznu kontinuitu, nemusí to tak byt. Bavorskí biskupi tvrdia, že v pasovskej diecéze pápežskí legáti ustanovili nové štyri biskupstvá. Kedže súčasne tvrdia, že Wiching bol za biskupa vysvätený mimo rámca Pasova (čím sa zriekajú práva nad Nitrianskom), je možné, že všetky štyri biskupstvá boli na území Moravy, resp. nezahŕňali Nitru. Táto hypotéza musí byṫ však podrobená hlbšej analýze a predpokladá, že biskupi podávajú pravdivú informáciü ${ }^{36}$.

Ak aj jeden z nových biskupov bol určený pre Nitru, nie je jasný další osud biskupstva. Okolo roku 907 Vel'ká Morava ako útvar zaniká, resp. rozpadá sa jej ústredná moc pravdepodobne po smrti Mojmíra II. Istotne nedochádza k celkovému kolapsu, ale atomizácii na menšie civilné

30 Viacerí autori predpokladajú, že sa tak stalo na základe žiadosti Mojmíra II, ktorý si uvedomoval dôležitost' samostatnej cirkevnej organizácie, nie je to však priamo zaznačené (Hrušovský 1988, 108-109).

${ }^{31}$ List písali salzburský arcibiskup Theotmar, frízinský biskup Uvald, eichstättský Erchanbald, brixenský Zachariáš, regensburský Tuto a pasovský Richarius (Summo pontifici; Summo pontifici 2011, 200; Bavorský episkopát pápežovi; Bavorský episkopát pápežovi, 1964, 207).

32 V uvedenom období bolo územie Velkomoravskej ríše menšie, než za Svätopluka. Okrajové a vzdialené územia odpadli prvé, Čechy sa pričlenili do závislosti od Frankov, stratila sa vel'ká čast Panónie. Je otázka, v akom rozsahu došlo $\mathrm{r} 899 \mathrm{k}$ obnoveniu provincie: či v pôvodnom, alebo v dobovo aktuálnom. Možno predpokladat, že územne sa týkala už len častí bezprostredne náležiacich pod Mojmírovu vládu. V takom prípade (vzhladom na počet biskupov) bola obnovená dokonca $s$ väčšou cirkevno-právnou silou, než pôvodne. Štyria biskupi tvorili dostatočný počet nielen na príslušné sviatostné úkony, ale boli spôsobilí svätit podla potreby i nových biskupov.

33 Súhrnne k diskusii J. Steinhübel (1994).

34 „Ved’ jedno biskupstvo je rozdelené na pät [...]“ (Summo pontifici; Summo pontifici 2011, 200; Bavorský episkopát pápežovi; Bavorský episkopát pápežovi, 1964, 208).

35 „Váš predchodca [...] vysvätil Wichinga za biskupa, avšak vôbec ho nevyslal do onoho starého Pasovského biskupstva, ale k istému na vieru obrátenému národu [...]“ (Summo pontifici; Summo pontifici 2011, 202; Bavorský episkopát pápežovi; Bavorský episkopát pápežovi, 1964, 208; Baláž 2015, 16).

${ }_{36}$ Vzhladom na skutočnost', že biskupi skreslujú viaceré fakty, mohli zamlčat aj skutočnost', že jeden z biskupov bol svätený pre Nitru. 
i cirkevné jednotky pod správou jednotlivých vel’možov, či cirkevných hodnostárov (Botek 2014, 153). Vel'komoravský štátny útvar tak postupne zaniká a pre nájazdové mad’arské kmene nepredstavuje väčšiu hrozbu. Možno predpokladat', že neznámy nitriansky biskup, ak nezahynul počas vojnových udalostí okolo roku 907, skončil svoje pôsobenie niekedy v 20-tych rokoch 10. storočia, a tým nitrianske biskupstvo zaniklo ${ }^{37}$. Jeho tradícia však pokračuje v existencii kapituly, ktorá vznikla možno už na prelome 9. - 10. storočia. V listine z roku 1006 sa uvádza, že prvý uhorský král' sv. Štefan (1000 - 1038) pri svojom príchode do Nitry tu našiel 9 kňazov - kanonikov (Judák 2011, 21). Kapitulu obdaroval výsadami, ale biskupstvo neobnovil, možno aj z toho dôvodu, že novovzniknuté ostrihomské biskupstvo sa temer zhodovalo s rozlohou pôvodného nitrianskeho biskupstva. K obnoveniu nitrianskeho biskupstva (pravdepodobne jednoduchým prechodom prepošstva na biskupstvo - Judák 2011,24) došlo až za krála Kolomana (1095 - 1116), pričom presný rok nie je známy ${ }^{38}$.

Sprievodnou otázkou je existencia biskupského chrámu. Cirkevná jurisdikcia potrebovala pre svoj plný výkon nielen formálne právomoci, ale na výkon kultu bol potrebný patrične reprezentatívny priestor, v rámci ktorého sa kult mohol vykonávat' (Botek 2014, 20). Uvedený predpoklad je o to dôležitejší, že nešlo o biskupa s osobnými právomocami, ako mohol byt’ biskup misijný, alebo spojený $\mathrm{s}$ istým reholným spoločenstvom ${ }^{39}$, ale o zriadenie diecézy v jej logických štruktúrach. V takejto situácii musel byt k dispozícii „hlavný“ biskupský - diecézny chrám. Takúto sakrálnu stavbu teda musíme predpokladat aj v Nitre. Žial', vplyvom nepretržitého kontinuálneho vývoja Nitry až do súčasnosti je možná nálezová situácia značne skomplikovaná. Nové a nové stavebné vrstvy zničili a prekryli staršie situácie, ktoré máme zachované len v mizivých fragmentoch, alebo sekundárnych polohách ${ }^{40}$. To je však skúsenostou výskumov mnohých európskych mestských lokalít - stav v Nitre je podobný viacerým sídelným útvarom, kde stavebná činnost̉ prebiehala počas stáročí kontinuálne a zničila, alebo prekryla staršie, listinne spomínané objekty ${ }^{41}$.

Význam Nitry ako cirkevného centra možno doložit už pred vznikom Velkej Moravy so známym údajom, že salzburský arcibiskup Adalram vysvätil Pribinovi na jeho majetku Nitrava kostol $^{42}$. Vysvätenie sa predpokladá v roku 828, ked’ Adalram sprevádzal krála Ludovíta na výprave proti Bulharom ${ }^{43}$. Otvorenou ostáva otázka, prečo kostol v Nitre - teda na území severne nad Dunajom, ktoré prislúchalo Pasovu, vykonal uvedený úkon salzburský arcibiskup - na tomto mieste ju však nebudeme riešit ${ }^{44}$. Hladanie Pribinovho kostola sa stalo témou dňa pri tisícroč-

37 Nezaniklo však osídlenie, dokonca nie je archeologicky zdokumentovaná vojenská pacifikácia Nitry a dokladá sa kontinuita v pochovávaní (Hájnik 2019, 117).

38 Zrejme v období rokov 1109 - 1110 (Bugan 2007, 59). V tejto súvislosti nie je celkom vyjasnená situácia so sv. Bystríkom, označovaným za nitrianskeho biskupa, ktorý zomrel počas domáceho povstania v roku 1046 spolu s biskupmi Gerardom a Buldusom a boli spoločne kanonizovaný (Bugan 2007, 76-80).

39 Wiching bol síce benediktín, ale jeho biskupská konsekrácia bola spojená s územnou diecézou a nie s osobnými kompetenciami.

40 Opačne je to napr. v lokalite Valy pri Mikulčiciach, kde po zániku Velkej Moravy osídlenie v podstate nepokračovalo a archeológovia mohli skúmat priame situácie bez neskorších zásahov.

${ }^{41}$ Napr. v Pasove je zaznačený kostol zo začiatku 5. stor., ktorý po roku 460 „skrášlil“ sv. Severín, avšak archeologicky nie je jednoznačne určený (Päffgen 2016, 288).

${ }^{42}$ Spomína to vsuvka v diele O obrátení Bavorom a Korutáncov (Conversio 2011, 11; Conversio 2011, 273).

43 Uvedený dátum, akceptovaný aj súčasnými historikmi, uviedol už roku 1835 nitriansky biskup Jozef Vurum (Bagin 1981, 43). Na tomto mieste nebudeme reflektovat zložitú otázku okolo dôvodu vysviacky kostola, ktorá je medzi odborníkmi diskutovaná hlavne z dôvodu, že Pribina je v dobovom zázname opisovaný ako pohan. Uvedená skutočnost’ sa vysvetluje rozlične a nechýbajú aj názory o jej spochybnení (súhrnne: Botek, 2018, 93-94).

${ }^{44}$ Len okrajovo spomeňme, že sa napr. predpokladá, že záujmové sféry boli jednoznačne vyčlenené až v roku 829, prípadne v tom niektorí vidia kompetenčné spory o naddunajské územie Pasova a Salzbutrgu 
ných oslavách roku 1933, pričom sa stotožňoval s východnou častou „Dolného kostola“ nitrianskej katedrály s apsidálnym záverom ${ }^{45}$. A to aj napriek negatívnym výsledkom archeologického výskumu, ktoré túto čast’ datovali do prelomu 12./13. storočia (Bednár - Poláková 2011, 186). Kontinuálna stavebná činnost’ v hradnom okrsku temer úplne zničila najstaršie nálezy. Niektoré nálezové situácie však umožňujú predpokladat’ v tomto priestore murovanú stavbu $\mathrm{z} 1$. polovice 9. storočia. Pod velkomoravským valom I sa našli na dvoch miestach maltové zhluky (stavebný odpad a zvyšok po miešaní), v samotnom vale sekundárne použitá stavebná sut’ a poukazuje sa na podobnost's maltou fragmentu muriva zisteného v severovýchodnej časti paláca (Bednár 2012, 148-149, Bednár - Ruttkay 2014, 231). Nálezy dokladajú neznámu murovanú stavbu na vrchole hradného kopca, ktorá bola s najväčšou pravdepodobnostou sakrálnym objektom, ktorým mohol byt' uvedený Pribinov kostol (Šalkovský 2019, 223).

Väzba medzi kostolom, vysväteným Pribinovi, a neskorším situovaním biskupstva do tohto sídla nebude iste náhodná (König 2017, 22). Môžeme predpokladat', že Nitra sa stala misijným centrom franského duchovenstva. Archeologické nálezy i fragmenty architektonických článkov svedčia o dalšej stavebnej aktivite v 2. polovici 9. storočia. Došlo k výstavbe obranného valu okolo celého obvodu hradného kopca. Na jeho vrchole vznikol nový rozsiahly stavebný komplex a došlo k výraznej prestavbe staršieho objektu, ktorú charakterizuje stavebný materiál $\mathrm{v}$ podobe kvádrikového muriva $\mathrm{z}$ bieleho litotamniového vápenca. Velké množstvo kvádrov druhotne použili $\mathrm{v}$ zásype komorového valu z 11. storočia a $\mathrm{v}$ murive neskorománskej časti kostola z prelomu 12./13. storočia (Bednár 2012, 149, Bednár - Ruttkay 2014, 232). Okrem fragmentov muriva sa našli aj časti dvoch architektonických článkov v sekundárnej polohe, jeden s reliéfnym zdobením na báze perlovca, druhý s trojakou dekoráciou rustikalizujúcich motívov (akantových listov, jazykov, ludských hláv) ${ }^{46}$. Väčšinou sa dokladá ich súvislost’ s karolínskym prostredím - výrazovo nepochopené tvaroslovie umožňuje uvažovat o 9. storočí (Bednár 2011, 118). Názor o antickom pôvode (napr. Steinhübel 2004, 13-14) nenašiel v odbornej obci zástancov. Zvyšky muriva sa nachádzajú sekundárne aj vo vale II, datovanom do začiatku 11. storočia (Bednár - Poláková 2011, 187). Je vysoko pravdepodobné, že k tejto prestavbe došlo v 2. polovici 9. storočia a to v súvislosti so vznikom nitrianskeho biskupstva ${ }^{47}$. Starší Pribinov chrám zrejme nevyhovoval novej reprezentačnej funkcii. Ak si uvedomíme, že biskupom sa stal Wiching, je logická karolínska proveniencia spomenutých architektonických článkov. Stavitelia pravdepodobne prišli z niektorej bavorskej dielne - analogicky môžeme spomenút stavitelov, ktorých poslal salzburský arcibiskup Liupram (836 - 859) Pribinovi na stavbu chrámu sv. Hadriána (Conversio 2011, 11; Conversio 2011, 275). O to skôr mohol získat takýchto stavitelov Wiching - aj z niektorej kláštornej huty.

Ak si uvedomíme, že v lokalite Valy pri Mikulčiciach, považovanej za mocenské centrum Velkej Moravy, sa doposial' archeologicky odkryli zvyšky 10 - 12 kostolov (v závislosti od interpretácie) a v aglomerácii Staré Město-Uherské Hradište (vo velkej miere narušenej mladšou zástavbou) je to 5 objektov a niekol'ko d’alších bez možnosti presného zaradenia, je jasné, že aj na území Nitry, ktorá bola jedným z vel'komoravských centier, muselo existovat viacero sakrálnych stavieb. Stáročný kontinuálny stavebný vývoj však má za následok nielen ich zánik, ale aj stratu ich stôp temer

(Špetko 1988, 29; Ruttkay 2012, 120). Salzburský arcibiskup Liupram svätil osobne kostoly Pribinovi a Kocelovi v Panónii. Kardash spomína, že niektoré územia v Panónii sa jurisdikčne menili ešte v 30-tych rokoch 9. storočia (Kardash 2019, 17-18).

45 Súhrnne o dobových názoroch napísal Peter Ivanič (2008, 60-69).

46 Tento druhý fragment sa najnovšie datuje na koniec 11. stor. (Samuel - Pomfyová - Buran 2017, 498).

47 Alternatívne sa uvažuje o úzkej väzbe murovaných stavieb s obdobím vlády Svätopluka I. (Hanuljak 2019, 78). 
bez zvyškov. Len výnimočne je možné narazit’ na fragmenty ranostredovekej architektúry. Možno spomenút napr. fragmenty sutiny s omietkou podobnou vel'komoravskej pri výkope na Kupeckej ulici, umožňujúce predpokladat sakrálnu stavbu v 9. storočí na predhradí (Ruttkayová - Ruttkay 1997, 109). Na základe datovania niektorých hrobov do velkomoravského obdobia v priestore niekdajšieho hradiska v polohe „Vŕšok“ (pri piaristickom kostole) sa pripúštala existencia dalšej sakrálnej stavby (súhrnne Fusek - Bednár 2008, 36). Ostatné vyhodnotenie hrobov ich charakterizuje ako rozptýlené $\mathrm{v}$ sídliskovom prostredí a teda ich vztah k predpokladanému kostolu sa nedá dokázat' (Hanuliak 2019, 81).

Velký počet sakrálnych stavieb na spomenutých dvoch moravských lokalitách viedol k hypotéze o tzv. „rodine kostolov“. V zásade ide o uplatnenie spôsobu rímskej „procesnej liturgie“, ktorá sa na väčšie slávnosti konala postupne v rôznych mestských kostoloch Ríma za účasti veriacich i duchovenstva. Jej prenos do západnej Európy súvisí s „rímskou imitáciou“ karolínskeho obdobia a vyskytoval sa vo všetkých väčších mestách a hlavne v biskupských sídlach. Práve tento zvyk, uplatňovaný vo franskom prostredí, mohol ovplyvnit i situáciu sakrálnej topografie na Velkej Morave a môžeme ho predpokladat' aj v Nitre (súhrnne Pomfyová 2010). Uvedený názor výrazne podporuje skutočnost', že Nitra bola silným cirkevným strediskom franského duchovenstva, a tak spomenutá prax i tu mohla viest’ k vzniku viacerých sakrálnych objektov, najmä po vysviacke Wichinga za Nitrianskeho biskupa. Preto by bolo logické očakávat’ v nitrianskom sídelnom okrsku nálezy viacerých sakrálnych architektúr.

Za jeden z takýchto objektov sa dlho pokladal nález staršej stavby na Martinskom vrchu, ktorá sa našla pod asanovaným románskym kostolom. Ide o jednolodie s rovným záverom, z ktorého sa okrem základového muriva lode miestami zachovali aj zvyšky nadzemného muriva svätyne. Autor výskumu datoval najstaršiu fázu do polovice 9. storočia a vyslovil názor o možnom stotožnení objektu s už spomínaným Pribinovým kostolom (Chropovský 1972, 194-195). Jeho tvarovú skladbu neinterpretoval správne - do jeho dľžky začlenil aj mladšiu západnú prístav$\mathrm{bu}^{48}$. Korekcia sa uskutočnila vd’aka revíznemu výskumu z rokov 1997 a 2005 (Ruttkay 2011, 60-61 $)^{49}$. Objekt bol omietnutý, na omietkových úlomkoch sa zachovali zvyšky freskovej malby $\mathrm{v}$ okrových a červených lineárnych vzoroch ${ }^{50}$.V nálezoch sa potvrdili aj zvyšky maltovej podlahy. B. Chropovský poukazoval na karolínsky typ stavby s rovným záverom, spomenul ale aj juhoeurópske - dalmátske príklady, a uviedol, že technika budovania základov - ukladania velkých kameňov pod nárožia - je analogická Pribinovmu zalavárskemu kostolu (Chropovský 1972, 181). Vzhl’adom na skutočnost', že masívna hrúbka murív je obdobná s príkladom z franského prostredia, sa uvažovalo, že objekt mohla stavat franská misia, možno ešte za Pribinovho pôsobenia (Štefanovičová 2001, 114). Pri ostatnom vyhodnotení novoodhalených situácií sa dnes nedá s určitostou potvrdit, či uvedená stavba spadá do obdobia Vel'kej Moravy, pretože chýbajú jednoznačne datované skutočnosti (aj vplyvom inváznych zásahov (Fusek - Bednár 2008, 36; Samuel 2015, 125) $)^{51}$. Datovanie do vel'komoravského obdobia nie je teda úplne vylúčené, ale predbežne spochybnené.

48 Chrám sa nachádzal v areáli využívanom armádou, preto bol jeho výskum časovo limitovaný. To spôsobilo aj urýchlené uzavretie výskumnej správy bez dostatočne podrobného zamerania a z toho plynúce nejednoznačné interpretácie pôdorysu, dokonca i rozdielne tvarové pomery.

49 Zistilo sa, že murivo bolo dodatočne výrazne narušené výkopmi pre trasovanie inžinierskych sietí - zničená bola temer celá južná stena, čast̉ západnej a aj svätyne. Mnohé predtým dokumentované úseky murív a základov zanikli. Po zmene užívatel'ských vztahov sa pristúpilo koncom roku 2013 k celkovému odokrytiu nálezov.

50 Analýzy preukázali, že na zlahka vyhladený povrch bola nanesená hustejšia, piesok obsahujúca kaša. Polychrómia bola nanášaná do čerstvej vlhkej masy v dvoch vrstvách (Hammer - Misar 2001, 148).

51 Diskutovaná je aj samotná existencia opevneného sídla (Šalkovský 2019, 224). 
Na území Nitry okrem už spomenutých nejednoznačných nálezov nemáme priame doklady vel'komoravských sakrálnych architektúr. Je otázne, či niektoré ranorománske stavby nemôžu stát na mieste zaniknutých vel'komoravských chrámov. Tu by bolo možné spomenút kostol sv. Štefana v Párovciach. Súčasný románsky kostol s polkruhovou apsidou je postavený na zvyškoch staršej stavby s apsidou podkovovitou. Autor výskumu najstaršiu čast̉ datoval do 10. storočia (Polla 1964, 14), so staršími názormi sa v súčasnosti polemizuje aj z dôvodu nedôsledného publikovania nálezových skutočnostín ${ }^{52}$. Najnovšie vyhodnotenie uvádza jeho vznik najneskôr na prelom 11. a 12. storočia (Samuel 2015a, 128). Jednoznačné odpovede môže dat' len nový výskum. Aj nedaleký dražovský Kostol sv. Michala je postavený na starších základoch s podkovovitou apsidou. Pôvodne sa predpokladalo, že bol súčastou zaniknutého zemepanského sídla. Dnešné poznatky síce zistené zvyšky opevnenia charakterizujú ako velkomoravskú tradíciu, na základe hrobov predpokladajú ich vznik v 11. storočí (Šalkovský 2019, 225). Najstaršia fáza kostola nie je spolahlivo datovaná, odrazit’ sa možno od druhej stavebnej etapy, pochádzajúcej asi z polovice 11. storočia (Paulusová 2011, 109), resp. zo začiatku 12. storočia (Samuel 2015b, 131). Obe spomenuté stavby nemajú zistené vel'komoravské substancie, ale principiálne nie je vylúčený ich vznik na miestach starších zaniknutých objektov. Naznačené súvislosti môžu implikovat' hustejšiu siet’ vel'komoravských sakrálnych objektov v intraviláne Nitry, resp. jej bezprostredného okolia.

\section{Záver}

Nitra si ako sídlo Pribinovho kniežatstva udržala svoje výnimočné postavenie aj v období Velkej Moravy, bola jedno z najrozvinutejších naddunajských sídel a stredisko civilnej i cirkevnej správnej štruktúry. Tento význam podčiarkuje i prvá písomná zmienka o vysviacke krestanského chrámu i neskoršie samostatné postavenie v rámci Velkej Moravy, ktoré sa prenieslo i do ranouhorského štátu. Stala sa strediskom franskej misijnej aktivity a možno i sídlom archypresbyteriátu. Nie je preto náhodné, že roku 880 bola práve ona zvolená za biskupské sídlo novosväteného biskupa Wichinga. Stret západnej a východnej cirkevnej koncepcie sa premietol do stretu Wichinga $\mathrm{k}$ arcibiskupovi Metodovi a vyústil neskôr do vyhnania Metodových žiakov. Dominantnost̉ franského kléru ostala zachovaná aj po odchode Wichinga do Arnulfových služieb. Možno oprávnene predpokladat', že po obnovení arcidiecézy v roku 899 bola Nitra jedným zo sídel nových hierarchov, ako to môžu naznačovat' i zmienky v neskorších listinách. Po definitívnom zániku Vel'kej Moravy nitrianske biskupstvo prežíva vo forme kapituly a k jeho obnoveniu dochádza až začiatkom 11. storočia. Kontinuálny rozvoj sídla zničil priame stavebné doklady biskupského sídla i chrámu. Z archeologických nálezov stavebných fragmentov však môžeme predpokladat sakrálne stavby na hradnom kopci i v terajšej mestskej zástavbe. Analogicky k situácii v iných vel'komoravských centrách môžeme predpokladat’ aj väčšie zoskupenie kostolov, možno na spôsob karolínskej „procesnej“ liturgie.

\section{REFERENCES}

Bača, Robert. 2016. K patrocíniu kostola sv. Margity Antiochijskej v Kopčanoch. In Slovenská archeológia LXIV/1, 145-176.

Barteková, Anna. 2014. Kostol sv. Štefana v Nitre - Párovciach. In Musaica XXVIII. Zborník Filozofickej fakulty UK. Bratislava, 163-190.

Bagin, Anton. 1982. Apoštolové Slovanů Cyril a Metoděj a Velká Morava. Praha.

52 A. Barteková $(2014,168)$ datovala túto čast najskôr do 11. storočia. 
Baláž, Peter. 2015. Pseudokrest’anskí Moravania, Nitrianski neofyti a najkrestanskejší Frankovia [Pseudo-Christian Moravians, the Neophytes of Nitra and the Earnest Christian Franks]. In Konštantínove listy [Constantine’s Letters] 8, 14-24.

Bavorský episkopát pápežovi. 1964. Bavorský episkopát pápežovi. In Ratkoš, Peter (eds.) Pramene k dejinám Vel'kej Moravy. Bratislava, 206-210.

Bednár, Peter. 2011. Počiatky nitrianskeho hradu. In Judák, Viliam - Bednár, Peter - Medvecký, Jozef (eds.). Kolíska krestanstva na Slovensku. Nitriansky hrad a Katedrála sv. Emerána v premenách času. Nitra, 114-121.

Bednár, Peter. 2012. Nitra v časoch pôsobenia sv. Konštantína - Cyrila a sv. Metoda. In Panis, Branislav - Ruttkay, Matej - Turčan, Vladimír (eds.). Bratia, ktorí menili svet - Konštantín a Metod. Bratislava, 145-156.

Bednár, Peter - Poláková, Zuzana. 2011. Katedrála sv. Emeráma. In Judák, Viliam - Bednár, Peter - Medvecký Jozef (eds.). Kolíska krestanstva na Slovensku. Nitriansky hrad a Katedrála sv. Emerána v premenách času. Nitra, 184-207.

Bednár, Peter - Ruttkay, Matej. 2014. Nitra. In Kouřil, Pavel a kol. (eds.). Velká Morava a počátky křestanství. Brno, 229-234.

Below, Georg von - Meinecke, Friedrich. 1907. Handbuch der mittelalterlichen und neueren Geschichte. Abteilung IV. München - Berlin, 1907.

Betti, Maddalena. 2014. The making of christian Moravia. Papal power and political reality. Leiden - Boston.

Botek, Andrej. 2014. Velkomoravské kostoly na Slovensku a odraz ich tradície v neskoršom období. Bratislava.

Botek, Andrej. 2018. K otázke možnej kanonizácie našich panovníkov z najstarších dejín. In Historický zborník 28/1. Martin, 91-116.

Bowlus, Charles. 1995. Franks, Moravians and Magyars. The Struggleforthe Middle Danube 788 907. Philadelphia.

Bugan, Bystrík. 2007. Svätý Bystrík. Bratislava.

Conversio. 2011. Conversio Bagoariorum et Carantanorum (Obrácení Bavorů a Korutánců), 2011. In Bartoňková, Dagmar - Večerka, Radoslav (eds.). Magnae Moraviae Fontes Historici III. Diplomata. Epistolae. Textus Historici Varii. Edicio secunda, revisa et aucta. Prameny k dějinámVelké Moravy III. Listiny, listy, různé historické texty. Druhé, revidované a rozšířené vydání. Praha, 253-283.

Curta, Florin. 2019. Eastern Europe in the Middle Ages (500-1300). Leiden.

Dopsch, Heinz. 1986. Passau als Zentrum der Slawenmission. Ein Beitragzur Geschichte des „Grossmährischen Reiches“. In Südostdeutsches Archiv 28-29, 5-28.

Fichtenau, Heinrich. 1964. Urkundenfälschungen Pilgrims von Passau. In Mitteilungen des Oberösterreichischen Landesarchivs 8. Linz, 81-100.

Fusek, Gabriel - Bednár, Peter. 2008. Die (vermutete) Kirche am Burgberg in Nitra (Slowakei). In Pippal, Martina - Heiko, Daim (eds.). Frühmittelalterliche Wandmalereien aus Mähren und Slowakei. Architektonischer Kontext und herstellungstechnische Analyse. Monographien zur Frühgeschichte und Archäologie 12. Innsbruck, 31-45.

Gallusová, Michaela - Herucová, Angelika. 2013. Konštantín a Metod v Panónii - zastavenie u Kocela. In Lukáčová, Martina - Husár, Martin - Ivanič, Peter - Hetényi, Martin (eds.). Tradícia a prítomnost' misijného diela sv. Cyrila a Metoda. Nitra, 110-120.

Galuška, Luděk. 2014. Křestanství v období byzantské misie a Metodějova arcibiskupství na bázi archeologických pramenůz oblasti Veligradu - Starého Města a Uherského Hradiště. In Kouřil, Pavel et al. (eds.). Cyrilometodějská misie a Europa. Brno, 74-85. 
Gluchman, Vasil. 2018. Ethics and Politics of Great Moravia of the 9th. Century. In Ethics and Bioethics (in Central Europe), Vol. 8/1-2. Warszawa, 15-31.

Goldberg, Eric, J. 2006. Struggle for Empire Kingship and Conflict under Louis the German, 817 876. Ithaka + London.

Hájnik, Jakub. 2019 Včasnostredoveké sekerovité hrivny z územia strednej Európy. In Musaica archaeologica 4/2, 111-172.

Hanuliak, Milan. 2019. Štruktúra vel'komoravského hradského mesta Nitrava na základe pochovávania. In Jenčík, Peter - Staneková, Zuzana (eds.). Hradiská - svedkovia dávnych čias II. Dolná Mariková, 75-89.

Hammer, Ivo - Misar, Matthias. 2001. Frühmittelalterliche Wandmalerei zwischen March- und Donautal - Vorbericht. In Galuška, Luděk - Kouřil, Pavel - Měřínský, Zdeněk (eds.). Velká Morava mezi Východem a Západem. Sborník př́íspěvků mezinárodní vědecké konference. Brno, 139-154.

Havlík, Lubomír, E. 1992. Kronika o Velké Moravě. Brno.

Hetényi, Martin. 2008. K platforme politiky Rastislava pred príchodom byzantskej misie [On the basis of Rastislav's policy before the Byzantine mission arrival]. In Konštantínove listy [Constantine's Letters] 1, 70-83.

Hnilica, Ján. 1988. Sv. Cyril a Metod - ich pomer k Sv. Písmu a vzájomné vztahy s Rímom. In Kružliak, Imrich - Hnilica, Ján (eds.). Prvoučitel’ národa slovenského. Zborník na pamiatku tisícstého výročia smrti sv. Metoda. Rím, 113-152.

Hrušovský, František. 1988. Styky slovenských kniežat so Svätou stolicou. In Kružliak, Imrich Hnilica, Ján (eds.) Prvoučitel’ národa slovenského. Zborník na pamiatku tisícstého výročia smrti sv. Metoda. Rím, 74-112.

Charvát, Petr. 2014. A montibus usquae ad mare: Morava a Benátky v 9. století. In Kouřil, Pavel et al. (eds.). Cyrilometodějská misie a Europa. Brno, 226-229.

Chropovský, Bohuslav. 1972. Príspevok k problematike cirkevnej architektúry a počiatkoch krestanstva na Slovensku. In Monumentorum tutela. Ochrana pamiatok 8. Bratislava, 173-208.

Illáš, Martin. 2011. Adriatický pôvod niektorých predrománskych kostolov v strednom Podunajsku. In ARS 44/2, 252-270.

Illáš, Martin. 2017. Niekolko úvah o Pribinovi, Mojmírovcoch a Velkej Morave (príspevok k diskusii o včasnostredovekých dejinách Moravy a západného Slovenska). In Moravský historický sborník. Ročenka Moravského národního kongresu 2011 - 2016. Brno, 179-247.

Ivanič, Peter. 2008. Pribinov kostol v Nitre v zrkadle historiografie [Problematics of Pribina’s church in Nitra from the perspective of historiography]. In Konštantínove listy [Constantine's Letters] 1, 60-69.

Ivanič, Peter. 2011. Západní Slovania v ranom stredoveku. História - kultúra - hospodárstvo náboženstvo. Nitra.

Judák, Viliam. 2011. Dejiny Nitrianskeho biskupstva. In Judák, Viliam - Bednár, Peter - Medvecký Jozef (eds.). Kolíska krestanstva na Slovensku. Nitriansky hrad a Katedrála sv. Emerána v premenách času. Nitra, 14-63 a poznámky na 472-476.

Kardash, Ostap. 2019. Проблема розмежування місіонерських сфер впливу латинських церковних діоцезів на пост-аварському просторі першої половини IX ст. (The problem of demarcation of the missionary spheres of influence of the Latin Church dioceses in the postAvar space during the first half of the 9th century. In Українсько-угорські етюди. Вип. 3. (Ukrainian - Hungarian Studies. Output 3.). Lwow, 6-34.

Kolník, Titus. 2012. Počiatky krestanstva v strednom Podunajsku vo svetle historických a archeologických prameňov. In Panis, Branislav - Ruttkay, Matej - Turčan, Vladimír (eds.). Bratia, ktorí menili svet - Konštantín a Metod. Bratislava, 9-46. 
König, Tomáš. 2017. The Great Moravian territory of Nitra. Cultural manifestations, territorial scope and the ethnic and social-political identity of its population. In Muzeológia a kultúrne dedičstvo 5/2, 9-28.

Kozmova kronika česká. 1964. Kozmova kronika česká. In Ratkoš, Peter (eds.) Pramene k dejinám Velkej Moravy. Bratislava,363-365.

Kožiak, Rastislav. 2006. Christianizácia Avarov a Slovanov na strednom Dunaji - príbeh svätcov-misionárov. Svätá vojna, alebo kultúrny šok? In Kožiak, Rastislav - Nemeš, Jaroslav (eds.). Svätec a jeho funkcia v spoločnosti I. Bratislava, 121-148.

Marsina, Richard. 1985. Metodov boj. Bratislava.

Marsina, Richard. 2013. Zápas o používanie slovanského jazyka v liturgii na Velkej Morave. In Lukáčová, Martina - Husár, Martin - Ivanič, Peter - Hetényi, Martin (eds.). Tradícia a prítomnost' misijného diela sv. Cyrila a Metoda. Nitra, 101-109.

MMFH III. 2011. Bartoňková, Dagmar -Večerka, Radoslav (eds.). Magnae Moraviae Fontes Historici III. Diplomata. Epistolae. Textus Historici Varii. Edicio secunda, revisa et aucta. Prameny k dějinám Velké Moravy III. Listiny, listy, různé historické texty. Druhé, revidované a rozšírené vydání. Praha.

MMFH IV. 2013. Bartoňková, Dagmar - Večerka, Radoslav (eds.). Magnae Moraviae Fontes Historici III. Leges, textus iuridici. Edicio secunda, revisa et aucta. Prameny k dějinám Velké Moravy IV. Zákony, právní texty. Druhé, revidované a rozšířené vydání. Praha.

Päffen, Bernd. 2016. Kirchen in der Raetia Secunda. In Strobel, Karl - Dolenz, Heimo (eds.). Akten des Internationalen Kolloquims Klagenfurt 6.-7. Dezember 2013. Graz, 277-320.

Paulusová, Silvia. 2011. Dražovce, románsky kostol sv. Michala - pamiatkový výskum a metodika obnovy. In Ranostredoveká sakrálna architektúra Nitrianskeho kraja. Nitra, 103-112.

Pieta, Karol - Ruttkay, Matej. 2018. Centrá Vel'kej Moravy a ich prezentácia. Nitra a Bojná. In Petrášová, Silvia (eds.) Monumentorum tutela/Ochrana pamiatok 29. Bratislava, 15-34.

Pohl, Walter. 2002. Die Awaren. Ein Steppenvolk in Mitteleuropa 567 - 822 n. Chr. Zweite, aktualisierte Auflage. München.

Pomfyová, Bibiana. 2010. Die Interpretationsmöglichkeiten der Sakraltopographie in Mikulčice. In Frühmittelalterliche Kirchen als archäologische und historische Quelle. Internationale Tagungen in Mikulčice VIII. Brno, 87-100.

Ratkoš, Peter. 1964. Pramene k dejinám Velkej Moravy, Bratislava.

Ruttkay, Matej. 2011. Možnosti prezentácie zaniknutých kostolov v Nitre na Martinskom vrchu. In Ranostredoveká sakrálna architektúra Nitrianskeho kraja. Nitra, 59-68.

Ruttkay, Matej. 2012. Mocenské centrá nitrianskeho kniežatstva. In Panis, Branislav - Ruttkay, Matej - Turčan, Vladimír (eds.). Bratia, ktorí menili svet - Konštantín a Metod. Bratislava, 115-144.

Ruttkayová, Jaroslava - Ruttkay, Matej. 1997. Výsledky výskumu v Nitre - Starom Meste v roku 1994. In Archaeologia historica 22. Brno, 103-113.

Samuel, Marián. 2015. Nitra, čast Chrenová, poloha Martinský vrch. Zaniknutý kostol sv. Martina. In Pomfyová, Bibiana et. al. (eds.). Stredoveký kostol. Historické a funkčné premeny architektúry. 1. zväzok. Bratislava, 122-125.

Samuel, Marián. 2015a. Nitra, poloha Párovská ulica. Kostol sv. Štefana krála. In Pomfyová, Bibiana et al. (eds.). Stredoveký kostol. Historické a funkčné premeny architektúry. 1. zväzok. Bratislava, 126-128.

Samuel, Marián. 2015b. Nitra, čast' Dražovce. Kostol sv. Michala archanjela. In Pomfyová, Bibiana et al. (eds.). Stredoveký kostol. Historické a funkčné premeny architektúry. 1. zväzok. Bratislava, 128-133. 
Samuel, Marián - Pomfyová, Bibiana - Buran, Dušan. 2015. Nitra. Katedrálny Kostol sv. Emeráma, Svorada a Benedikta. In Pomfyová, Bibiana et al. (eds.). Stredoveký kostol. Historické a funkčné premeny architektúry. 1. zväzok. Bratislava, 493-511.

Selucký, Pavel. 2010. Sv. Kliment u Osvětiman a Velká Morava. Koryčany.

Steinhübel, Ján. 1994. Štyri vel'komoravské biskupstvá. In Slovanské štúdie 38/1, 21-39.

Steinhübel, Ján. 2004. Nitrianske kniežatstvo. 1. vydanie. Bratislava - Budmerice.

Steinhübel, Ján. 2014. Metodov konflikt s bavorskými biskupmi. In Kouřil, Pavel et al. (eds.). Cyrilometodějská misie a Europa. Brno, 220-225.

Summo pontifici. 2011. Summo pontifici et universale papae, non unius urbis, sed tocium orbis domno, Johani, Romane sedis magnifico gubernatori / Nejvyššímu veleknězi a všeobecnému papeži Janovi, pánu nikoliv jediného města, nýbrž celého světa, vznešenému správci římské stolice, 2011. In Bartoňková, Dagmar - Večerka, Radoslav (eds.). Magnae Moraviae Fontes Historici III. Diplomata. Epistolae. Textus Historici Varii. Ediciosecunda, revisa et aucta. Prameny k dějinámVelké Moravy III. Listiny, listy, různé historické texty. Druhé, revidované a rozšířené vydání. Praha, 196-208.

Šalkovský, Peter. 2019. K územným zoskupeniam slovanských hradov vo včasnom stredoveku. In Jenčík, Peter - Staneková, Zuzana (eds.). Hradiská - svedkovia dávnych čias II. Dolná Mariková, 221-236.

Šášky, Ladislav. 1981. Kamenná krása našich miest. Bratislava.

Škoviera, Andrej. 2010. Svätí slovanskí sedmopočetnici. Bratislava.

Škoviera, Andrej (ed.). 2013. Pramene o živote svätých Cyrila a Metoda a ich učeníkov. Bratislava. Špetko, Jozef. 1988. Kristianizácia Slovienov v predcyrilometodskom období (od 5. až do polovice 9. storočia). In Kružliak, Imrich - Hnilica, Ján (eds.). Prvoučitel’ národa slovenského. Zborník na pamiatku tisícstého výročia smrti sv. Metoda. Rím, 11-31.

Štefanovičová, Tatiana. 2001. Architektúra Velkej Moravy v európskom kontexte. In Galuška, Luděk - Kouřil, Pavel - Měř́nský, Zdeněk (eds.). Velká Morava mezi Východem a Západem. Sborník př́íspěvků mezinárodní vědecké konference. Brno, 397-406.

Tönsmeyer, Hans Dieter. 2013. In castro Chezilonisnoviter Mosapurc vocato. In Kocel'a Blatnohrad. Marianka, 25-65 a 66-131.

Vavák, Július. 2015. Včasnostredoveké hrady na juhozápade malých Karpát. Ich vznik, význam a úloha. In Hradiská - svedkovia dávnych čias. Zborník odborných príspevkov o hradiskách a ich obyvateloch. Dolná Mariková, 101-126.

Zubko, Peter. 2014. Kult svätých Cyrila a Metoda v latinskej Cirkvi. Ružomberok

Život Klimenta, 2013. Život Klimenta od Theofylakta Ochridského. In Škoviera, Andrej (ed). Pramene o živote svätých Cyrila a Metoda a ich učeníkov. Bratislava, 99-136.

Život Metoda, 2013. Život Metoda. In Škoviera, Andrej (eds). Pramene o živote svätých Cyrila a Metoda a ich učeníkov. Bratislava, 45-56.

doc. Mgr. Ing. arch. Andrej Botek, PhD.

STU in Bratislava

Faculty of Architecture

Institute of History and Theory of Architecture and Monument Restoration

Námestie slobody 19

81245 Bratislava

Slovakia

and.botek@stuba.sk 
Comenius Univesity in Bratislava

Faculty of Roman Catholic Theology of Cyril and Methodius

Chair of Church History

Kapitulská 26

81458 Bratislava

Slovakia

botek@frcth.uniba.sk 


\section{Prílohy / Appendix}

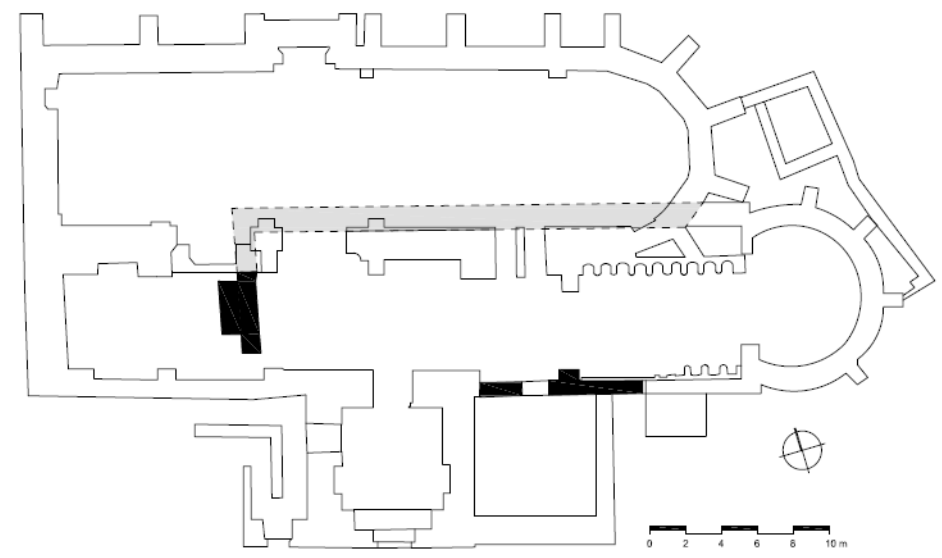

Obr. 1 Pôdorys Nitrianskej katedrály s vyznačením najstarších zistených častí. Fragment v južnom múre pripúšta dendrochronologické meranie do druhých dvoch tretín 10. stor. Zdroj: Botek, 2014, 97. Autori: Erdélyi, Robert - Vachová, Barbora, podla Petra Bednára.

Fig. 1 Ground plan of the Nitra - Cathedrale with an indication of the oldest parts found. The southern wall's fragment allows according to the dendrochronological measurements untill the second two thirds of the 10th century. Source: Botek, 2014, 97. Authors: Erdélyi, Robert - Vachová, Barbora, according to Peter Bednár.

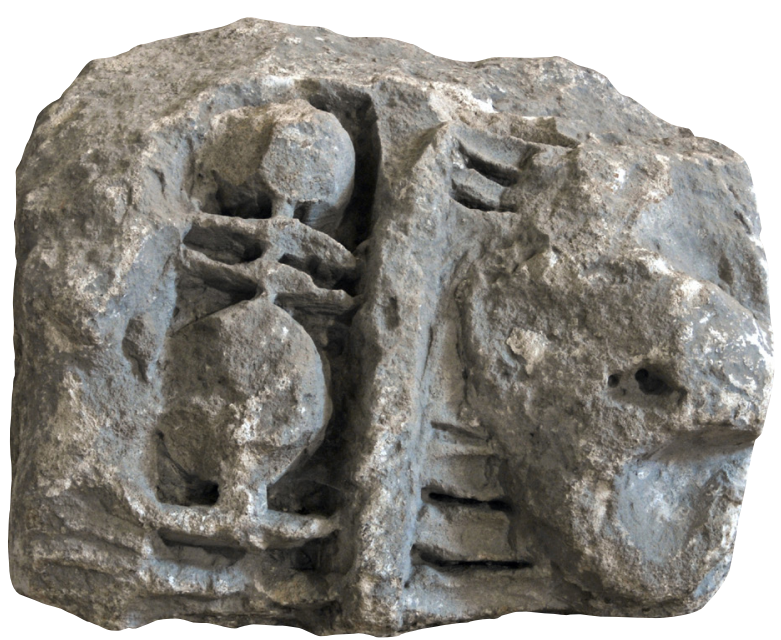

Obr. 2a Kamenný článok z predpokladanej prestavby nitrianskeho hradného kostola z 2. pol. 9. stor. Foto: Vladimír Plekanec.

Fig. 2a The stone figure from the expected rebuilding of the castle - church in Nitra from the 2nd half of the 9th century. Photo: Vladimír Plekanec. 


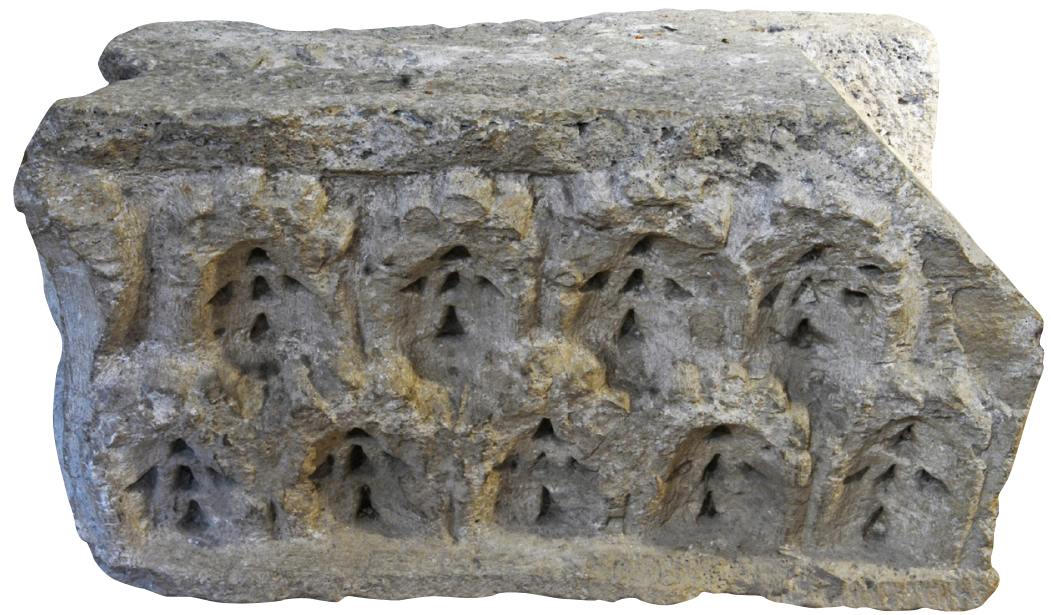

Obr. 2b Kamenný článok z predpokladanej prestavby nitrianskeho hradného kostola z 11. stor. Foto: Vladimír Plekanec.

Fig. $2 \mathbf{b}$ The stone figure from the expected rebuilding of the castle - church in Nitra from the 11th century. Photo: Vladimír Plekanec.

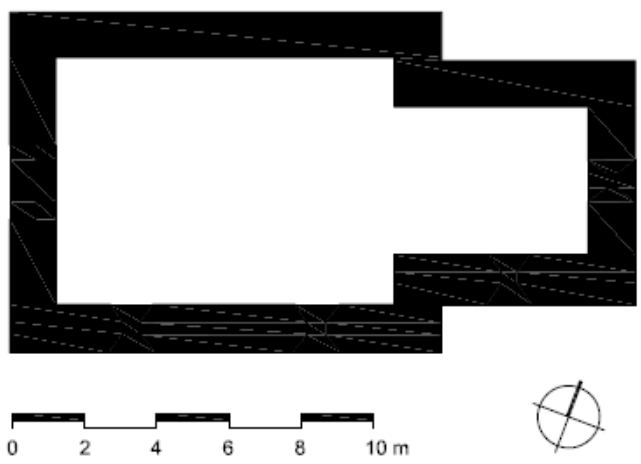

Obr. 3 Pôdorys najstaršej fázy kostola na Martinskom vrchu podla najnovších výskumov. Zdroj: Botek, 2014, 92. Autori: Erdélyi, Robert - Vachová, Barbora.

Fig. 3 Ground plan of the oldest phase of the church on Martinský vrch according to the newst investigations. Source: Botek, 2014, 92. Authors: Erdélyi, Robert - Vachová, Barbora. 


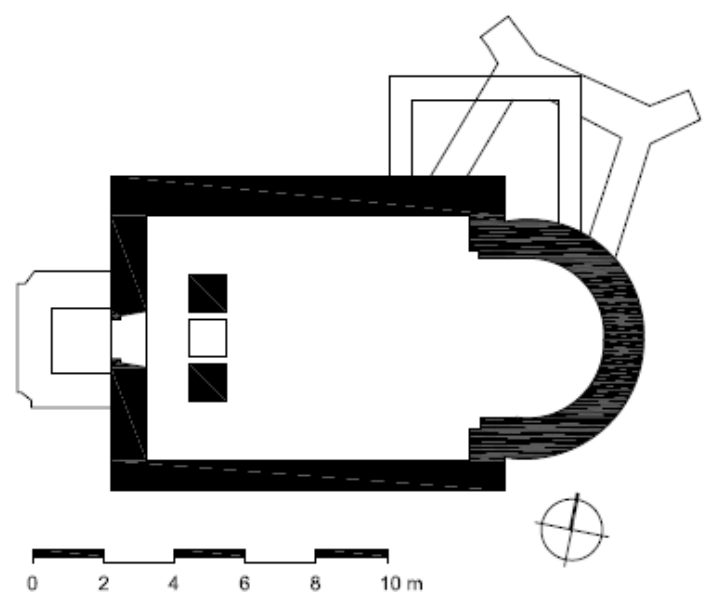

Obr. 4 Pôdorys najstaršej fázy kostola v Nitre - Párovciach. Zdroj: Botek, 2014, 171. Autori: Erdélyi, Robert - Vachová, Barbora, podla Anny Bartekovej.

Fig. 4 Ground plan of the oldest phase of the church in Nitra - Párovce. Source: Botek, 2014, 171. Authors: Erdélyi, Robert - Vachová, Barbora, according to Anna Barteková.

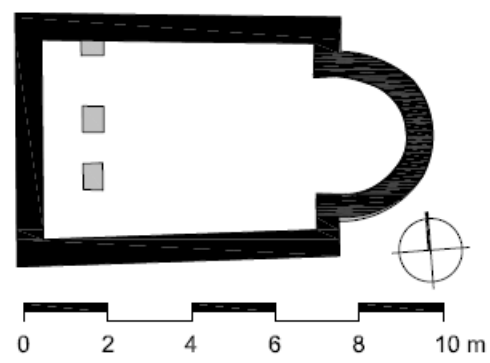

Obr. 5 Pôdorys najstaršej fázy kostola v Drážovciach. Zdroj: Botek, 2014, 92. Autori: Erdélyi, Robert - Vachová, Barbora, podla Silvie Paulusovej.

Fig. 5 Ground plan of the oldest phase of the church in Drážovce. Source: Botek, 2014, 92. Authors: Erdélyi, Robert - Vachová, Barbora, according to Silvia Paulusová. 